American Journal of Agricultural and Biological Sciences 3 (4): 673-680, 2008

ISSN 1557-4989

(C) 2008 Science Publications

\title{
People Participation, an Undeniable Necessity for Conserving Forest Areas of Arasbaran Region in Iran
}

\author{
${ }^{1}$ Sara Zare, ${ }^{2}$ Hossein Shabanali Fami and ${ }^{3}$ Manouchehr Namiranian \\ ${ }^{1}$ Department of Forestry, Tehran University, Karaj, Iran \\ ${ }^{2}$ Department of Agricultural Extension and Education,
}

Faculty of Agricultural Economics and Development, Tehran University, Karaj, Iran

${ }^{3}$ Department of Forestry, Faculty of Natural Resources, Tehran University, Karaj, Iran

\begin{abstract}
The issue of participation has recently become an interesting point for many national, regional and international institutions. Participation and collaboration of Iranians in the field of natural resources conservation has an old history. During a long period of time, vast areas of natural resources have been protected by the dwellers and indigenous users; we are witnessing deep land use changes in the fields of natural resources so that we can observe its negative impacts in different places because of changes in the traditional systems of exploitation, decentralization, lack of appropriate alternative participatory system, population growth, poverty and lack of adequate knowledge of users,. It is while, the villagers and forest's inhabitants, play an important role in managing of natural resources particularly in forested areas. It is because they have an indigenous knowledge which can be used in the process of natural resources management. Among Iranian forests, Arasbaran Region has a significant ecological value for the whole country as well as regional ecosystems. Hence, for protecting the forests of this region, people participation is inevitable. For an appropriate participatory forestry in this region, first of all there must be an adequate awareness about inhabitants of region. For this purpose, many methods such as PRA or RRA can be used. In the present research, Arasbaran forested region was investigated and people collaboration and participation with respect to the developing and protecting of forests of the region were analyzed using Participatory Rural Appraisal (PRA). Accordingly, this research tried to spotlight the people participation in the protection of natural resources. The results revealed that, expanding people's participation in this field depends on informing local people, decentralizing management process, reducing poverty, facilitating and improving the participation mechanism.
\end{abstract}

Key words: Forest coverage, forest, people participation, sustainable development, Participatory Rural Appraisal (PRA), Rapid Rural Appraisal (RRA)

\section{INTRODUCTION}

Needless to say, forests are important not only for production of timber and other products, but also for conservation of biodiversity, water generation and prevention of global warming. Forests and the forest industries have an important role to play. The contribution of forests to the environment, biodiversity and climate change is unquestionable. In addition, the potential social and economic benefits provided by forests can be considered equally important.

In the recent years, participation of people in forestry is one of the most important issues for a better conservation. Participation is an effort to increase control over resources and regulative institutions in given social situations, on the part of groups and movements of those hitherto excluded from such control $^{[5]}$ (UNRISD, 1979). Accordingly, during the last decade, participatory approaches to different forestry operations have been emerged.

At its simplest, a participatory approach is a commitment to equity in forest management. Participation helps to ensure that local people can share in the benefits of forestry and can make decisions about forestry matters that affect their livelihood. Its purpose is to ensure that forest management makes a real contribution to secure local livelihoods and that by doing so it also secures the future of the forest resource $^{[8]}$.

Corresponding Author: Sara Zare, Department of Forestry, Tehran University, Karaj, Iran Tel: ++98-21-22735570/++98-9123330843 
In fact, participatory forestry can conduct the activities of people in forests. From the view of this approach rural people and forest residents play an important role in forest management.

One of the common participatory forestry forms is called "community forestry". The objectives of Community Forestry (CF) are to emphasize the conservation, protection and subsistent use of the forest for the dwellers in watershed basins.

To establish the community forestry, stakeholders play very important roles in contributing the efforts in every stage to access to the formation of this project. Local people are the key actors, who proposed and raised the problems of the current situation within their communities.

Keeping this in view the overall goal of CF is defined as 'to increase the welfare of local communities through the introduction of ecologically adapted natural resource management practices, ${ }^{[2]}$.

Moreover, communication has become a key feature of sustainable development. The opening for this field known as "Communication for Development" comes from the recognition that in sustainable development there are multiple stakeholders all generating and exchanging information. This is especially true in natural resource management ${ }^{[11]}$.

Nowadays, it is believed that success in community-based approaches to forestry and natural resource management promises to deliver both sustainable resource management and secures livelihoods for rural communities ${ }^{[3]}$. In fact, participatory approaches need a flexible internal organization, sufficient space for feedback, discussion and analysis and new management styles that provide sense of ownership". The latest is very important for efficient forest management ${ }^{[1]}$.

In CFs, people should have a strong sense of ownership which becomes stronger by receiving the CF ownership certificate upon approval of their CF management plan. It is a symbiotic relationship between tribal people and conservation. Only an inclusive forest management system can secure the active participation of people in conservation. In the absence of tenure rights, it can hardly be expected that people develop a sense of ownership to forest land and consequently, care about forests. Once the tribal people secure their own land, they will have the incentives to protect the forests in the vicinity ${ }^{[17]}$.

AS briefly, mentioned earlier, community forestry faces many challenges. The main obstacles to community forestry include the followings:

Legal frameworks, Tenure, Conflicting policies, Lack of alternative sources of income, Conservative, traditional foresters, some government officials have negative attitudes toward local people and Knowledge and Skills.

Forest management in IRAN: Forests in Iran are defined as a vegetation cover where trees are its main elements. They are divided into various types according to superficial and inner situation and dominated by especial ecological conditions in respect of flora, fauna, climatic and edaphic factors ${ }^{[10]}$. Because of its large size and varied ecosystems, the Islamic Republic of Iran is one of the most important countries in the Middle East and Western Asia for conservation of biological diversity. Iranian habitats support some 8,200 species of plants, of which almost 2,500 are endemic. There are also 12.4 million hectares of woodland and some 8,900 hectares of mangroves along the southern coasts of Iran. Having forests with an area of nearly $12.4 \mathrm{mil}$ ha (7.4\% of the country total area), it has various geographic conditions, producing different forests of various tree and shrub species and production capacity in different edapho- climatic conditions. Iran is divided into vegetation regions as follows:

- Irano-Touranian Plains (ITP): Arid and semi-arid plains and deserts

- Irano-Touranian Mountains (ITM): Arid and semiarid mountains

- Zagrosian (Z): Semi-arid Zagros Mountains

- Hyrcanian (H): Semi-humid and humid Arasbaran and Hyrcanian mountains and Caspian plain

- Khalijo-Ommanian (KO): Dry southern coastal plains with high humidity

Up to 1960 , one of the greatest factors contributing to forest degradation in Iran was fuel wood production for supplying that as a result led to the expansion of rangelands in the country. In 1962, the whole forests of the country became nationalized. In addition in Iran, forestry is in the hands of the Forestry and Range Organization, under the Ministry of Jihade-Keshavarzi (Agriculture). The Forestry and Range Organization gives special importance to rural development and people involvement in afforestation activities ${ }^{[10]}$.

The forest policy in Iran: Forest protection is one of the most important objectives of the Forest and Range Organization. The government has a policy to engage local people in all forest activities, especially in forest protection. Since forests in Iran cover less than 10\% of the total land area (LFCC), the main objective of the national forest policy is to protect forests in natural ecosystems. In the national forest policy and forest 
protection strategies, priority has been given to rehabilitation and sustainable forest management of environmentally critical areas ${ }^{[9]}$.

Community Forestry (CF) in Iran: Iran Possesses rich traditional knowledge for the management of natural resources. Traditional knowledge is a cumulative body of knowledge, know-how, practices and representations maintained and developed by people with extended histories of interaction with the natural environment. These sophisticated sets of understandings, interpretations and meanings are part and parcel of a cultural complex that encompasses language, naming and classification systems, resource use practices, ritual, spirituality and worldview. Traditional and local knowledge systems as dynamic expressions of perceiving and understanding the world, can make and historically have made, a valuable contribution to science and technology and that there is a need to preserve, protect, research and promote this cultural heritage and empirical knowledge ${ }^{[13]}$. Nowadays particularly in forestry application of traditional knowledge is becoming widely popular. Based on a research study the Extension and Public Participation Bureau is studying and collecting traditional knowledge in the fields of forestry, silviculture, range management, afforestation and watershed management and apply the results in executive plans. Basically the involvement of local communities and traditional knowledge holders are in this process centrally. Traditional knowledge supports sustainable forest management in two ways. Firstly, it prevents waste of financial resources and secondly, the local communities accept to participate in forestry plans.

The complexity of forests and a long history of human settlements in these areas of Iran have created traditional modes of resource allocation. Accepting and even taking advantage of limitations and constraints imposed by the environment by adoption of a territorial organization of resource allocation i.e., nomadic. Iran has started to appreciate the specificities of forests. However, it has traditional knowledge and experience is somewhat lacking in scientific experience ${ }^{[7]}$.

Indigenous knowledge and local communities play a paramount role in the conservation and maintenance of the forests and natural perspectives, in Arasbaran area. Moreover, livelihood style of rural people in Arasbaran promotes the balance between the man and environment. In fact, knowing about indigenous knowledge and the way people being linked to the natural resources can help responsible managers to design forestry projects based on the realities of people- forest relationship in the forested areas. That is why participatory forestry has been emerged and developed during the recent decades.

In Iran, the forests are owned by the government and forestry projects are carried out in the framework of forest management plans prepared, approved and supervised on the basis of specific principles and guidelines. Since 1997, the following economic and policy instruments have been applied to attain sustainable forest management in $\operatorname{Iran}^{[7]}$ :

- Support participatory process in planning, implementing, monitoring and evaluating of forestry plans

- Support and encourage private sector, local communities and NGOs involvement in forest policy

- Delineate and specify the boundaries of private forest and range lands

- Organize training programs and provide technical services to participant's contribution in forest certification

Arasbaran region: Arasbaran Biosphere Reserve is located in the northern part of the Islamic Republic of Iran at the border to Armenia and Azerbaijan, belongs to the Caucasus Iranian Highlands, Straddling between the Caspian Sea and the Black Sea ${ }^{[16]}$, in Azarbaijan province (Kalibar town) approximately $90 \mathrm{~km}$ northeast of Tabriz.

It covers an area of about 164000 hectares and has a variety of natural features such as high mountains, deep valleys, steep slopes, dense forests and vast rangelands. The region has an important role in soil conservation, regulation of hydrology of surface and underground water, wildlife protection, biological diversity and supplying fuel wood requirements.

The territory of Arasbaran Biosphere Reserve is characterized by a high diversity of flora and fauna. The area supports many plant species, many of which are endemic. The fauna of the reserve is composed of a rich variety of birds, fishes, reptiles and mammal species. In addition to public importance for green cover creation, this forest is one of the global genetic resources because of having a vast biodiversity.

The majority of the population depends on farming in Arasbaran. Most of the village lands are under customary tenure, but the purchasing and borrowing of lands are practiced as well. Other sources of income include small business and wage labors. The residents had little access to formal education and agricultural extension services and very limited exposure to modern technologies. 
Kalibar is one of the counties located in the Arasbaran area of East-Azerbaijan Province. It covers an area of about 3630 square kilometers. Its population is about 92260 according to the last census of 1996. As compared with the other areas of the province, it consists $7.7 \%$ of the total land and its population density is about 25.4 people per square kilometer. Kalibar country contains three cities and three districts.

\section{MATERIALS AND METHODS}

This study was carried out in Hejrandoost Village of Kalibar County located in Arasbaran forested region of Iran. There are about 61 households in the Hejrandoost village. Almost all of the households were indigenous farmers. The most important crop was wheat.

PRA (Participatory Rural Appraisal) techniques were the major methods used to gather and analyze the data.

Participatory Rural Appraisal (PRA) was a label given to a growing family of participatory approaches and methods that emphasize local knowledge and enable local people to make their own appraisal, analysis and plans. PRA uses group animations and exercises to facilitate information sharing, analysis and action among stakeholders.

The orientation of a Participatory Rural Appraisal (PRA) is to facilitate or stimulate community awareness and capability regarding a problem or issue. In PRA, particular attention is given to enable local people to conduct their own analysis of problems and to share their findings.

IN Arasbaran (Hejrandoost village), the project of participatory forest management trained facilitators through a 4-day advocacy training. The facilitators were some of M.Sc. students from Forestry Department of the University of Tehran who were trained properly in conducting PRA sessions in rural areas. A meeting was organized by both rural women and men, who all participated in the mapping exercises as well as the discussion about the explanation use patterns and management priorities in the forest areas. An appropriate time and location were selected by which the meeting would not interrupt activities or be disturbed. Meeting was taken place in the village mosque. Mapping and Ranking were two techniques of PRA that were used in this research. In addition, the facilitators were interviewed using a semi-structural interview. The key questions related to the study and issues were identified during information collection were discussed during the meetings. They were asked about the strategies and approaches of the committee in increasing the participation of villagers in decision making processes.

\section{RESULTS AND DISCUSSION}

PRA techniques can be combined in a number of different ways, depending on the topic under investigation. The methods used in this case-Arasbaranwere mainly semi-structured interviewing with the villagers, preference ranking and mapping.

Mapping and modeling are good techniques to start with, because they involve several people, stimulate much discussion and enthusiasm, provide the PRA team with an overview of the area and deal with no controversial information ${ }^{[4]}$. Other tools common in PRA are ${ }^{[18]}$ : Semi structured interviewing, Focus group discussions, Preference ranking, Mapping and modeling Seasonal and historical diagramming.

Participatory Rural Appraisal (PRA) methods are useful for gaining a preliminary understanding of the research area in a relatively short period, usually between three days and three weeks ${ }^{[12]}$. PRA can help generate information on the socioeconomic and ecological conditions prevailing in the research site prior to the collection of more quantitative biophysical and economic data ${ }^{[14]}$.One of the functions can be in Forest Resources Management.

In PRA, visual techniques maps and diagrams were used because they encourage people to get involved in the process, to express the information in a way that is easily intelligible to them, to discuss issues amongst themselves and to add, refine and correct this information ${ }^{[6]}$.

The drawing of the map or diagram is not an end in itself-it is a tool for facilitating discussion, so once the map/diagram has been drawn it should be used as a basis for asking questions. It may be necessary to make some revisions to take account of points raised in the discussion. Generally speaking, people find it quite easy to make maps of natural resources and enjoy doing so $^{[15]}$.

Preparation of village social map by the villagers generated ample information about the demographic characteristics of the village.

Maps reflect the locations of villages, forests, agricultural lands, water resources, as well as management issues. The process of designing the map and the discussions that occur while it is being made are important outputs of the exercise. Map information can be transferred to a paper and digitized so that it is documented as a valid reference in future.

The success of community forestry-oriented PRA studies depends on the active participation of villagers 
and forestry field staff. Team members need to explain the purpose of the activity, describe how it would assist the community and develop a friendly relationship with them. It is important that the facilitating PRA team takes time to carefully prepare, developing a strategy for community discussions and a process to move from one step to the next.

In Hejrandoost village, students explained the purpose of the exercise and requested participants to draw a map of their village. It was also important to undertake an initial site visit with key information so that the researchers could become more familiarized with the prominent landmarks and build rapport with the community. It was helpful for an assertive village participant (such as a schoolteacher) to initially demarcate the roads, settlements and rivers. Community participants were respected by the community and included women whose knowledge of the forest was different and whose contribution was vital. The students acted as facilitator and encouraged the community to map from their own perceptions by asking simple, open-ended questions. The students started by asking the participants what feature they want to represent first, (road, river, etc) and ask what color and symbol they want to use to represent the features. It was important to ask where the open access areas are. The villagers then proceeded with a discussion of other important characteristics and expressing useful information about their surroundings. This process all took place in the mosque.

According to the maps drawn, they perceive the forest as part of their village and livelihood. Sense of ownership or belongingness to the forest can also be quietly observed from the information obtained through resource mapping. Majority of the respondents consider no border between their villages and the Para-forests (Fig. 1). It might be due to their strong dependency to the forest to secure their livelihoods.

In some of the maps, they have indicated a part of forest as grazing location of their livestock (Fig. 2).

From the viewpoint of the children, lack of access to school is a main problem, while the youths were mostly concerned about poor livelihood.

In some figures cultivated lands located around the village housing area (Fig. 3).

The girls prepared the requested maps more precisely than the others, so that they referred to all the details. It might be concluded that the young generation of the village is more resourceful for local community development. In some of maps, the distance between the village and Kalibar capital (Fig. 4). They mentioned that the long distance between the village and the area capital (Kalibar city) is one of the major problems inhibiting them to have an effective relationship with the city.

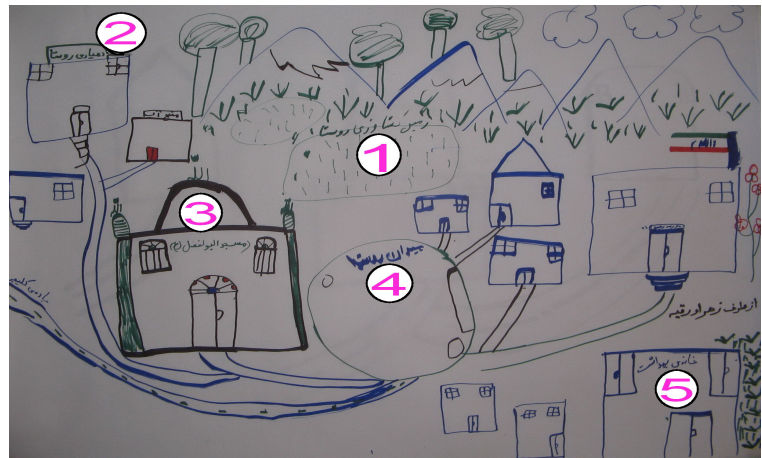

Fig. 1: The respondent perception about the proximity between the village and forested area. (1): Cultivative lands and forests; (2): Dehyari (Village body management); (3): Mosque; (4): Village square; (5): Helth care house (local clinic)

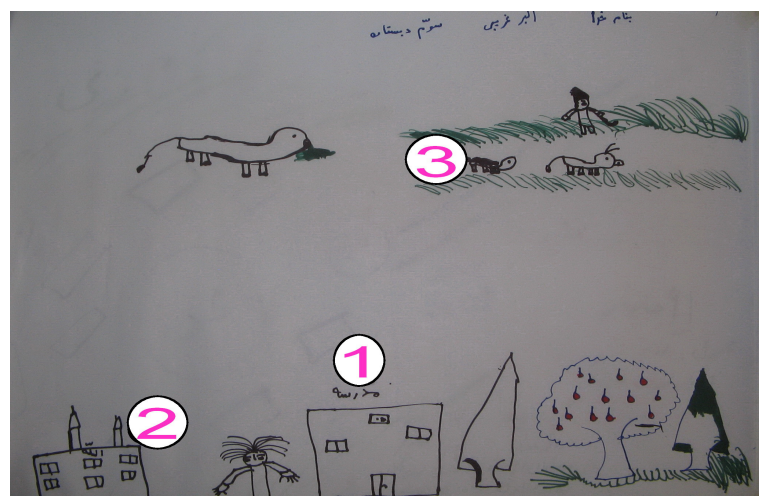

Fig. 2: Forests are considered as grazing area for the village livestock. (1): School; (2): Mosque; (3): Forest

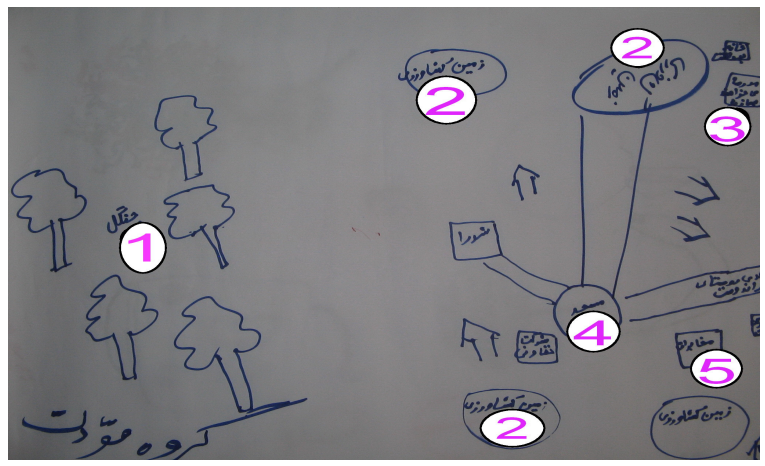

Fig. 3: Cultivated lands located around the village housing area. (1): Forested area; (2): Cultivated lands; (3): School; (4): Mosque; (5): Telecommunication center 


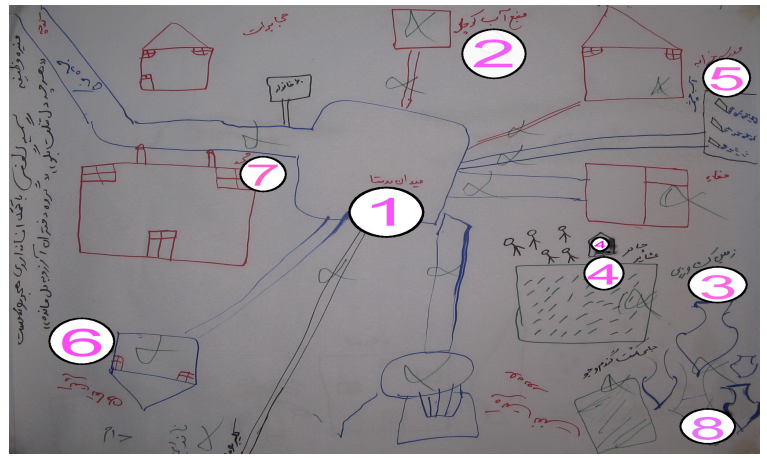

Fig. 4: Determining the distance between Kalibar and Hejrandoost village. (1): Village square; (2): Water sources; (3): Cultivated lands; (4): Tribes tents (awning); (5): Ruined school; (6): Cooperative center; (7): Mosque; (8) Forested area

In the map they emphasized that the school of the village is out of well-functioning limiting people access to qualified educational facilities and as a result may be reflected in their participation pattern in forestry management.

The facilitators soon understood that ranking is a good icebreaker in a group interview and helps focus the discussion. They perceived that it is a useful tool for assessing the relative importance of different activities in people livelihoods. Once the main livelihood problems were identified, participants should be asked what criteria they think are important when making comparisons between them. When these were agreed, the solutions of these problems were written and then ranked in importance. Ranking also contributed to ascertaining the contribution of forests and their products to livelihoods ${ }^{[4]}$.

Ranking is a rapid method to gain people insights about the factors affecting better forestry management.

In Hejrandoost village, for ranking step, the students selected a time when ranking was less likely to cause disruption to local activities or be disturbed. It involved a wide cross-section of participants and explained the aim of the exercise. In both ranking and scoring it was important that all the participants had a similar understanding of the criteria by which the participants were developing their preferences for a particular problem. The researchers attempted to identify these criteria as it provided insight into the value system associated with the different problems for a given use. Villagers in Hejrandoost divided into several groups and wrote their village problems such as educational, welfare and public health problems. When the problems were written by the villagers (with the student's help), they wrote solutions for each problem in the other papers.

Thereafter, the problems and solutions were classified, the repeated problems were deleted and then the people were asked to prioritize the problems once again.

The problems priorities were as follows:

- Educational problems for youth

- Welfare problems and accessibility to public services

- Problems with natural resource organization

- Health problems

As observed in the given data and information, natural resources problems were even perceived more important than health problems which might be due to the dependency of forest dwellers to the forest resources to secure their objectives.

In Hejrandoost village, for semi-structural interview, the students prepared the topics for discussion and identified the individuals or groups they want to talk to. Then selected an appropriate time to conduct the interview, asked open-ended questions that promote discussion and allowed for flexibility in discussion so the issues that arise could be fully explored. One of the students took notes. After the interview, the facilitators discussed the information and wrote-up a report.

During the primary interview, the researchers attempted to make rural people confident about the goals of the study. Rural people at Hejrandoost village mentioned that they were interested in participating in the government-designed poverty reduction programs. They believed forest conservation projects limit their farming and livestock raising activities and as such the government has to introduce alternative incomegenerating activities to the rural people. Since, natural resources are the main basis for rural people livelihood; any forest management project should take into account to prevent caponizing people lives. However, the researchers observed a strong relationship between rural poverty and forest degradation. Accordingly, poverty elimination is one of the basic prerequisites for sustainable forest management. Hence, any participatory forestry project is not successful unless notice rural economy pattern and economic dependency of forest dwellers to the forest. The study showed that participatory forestry approach is not successful without giving due to attention to the local rights at people living inside or around forested areas with respect to their long tradition at exploiting forest resources to sustain their livelihood. 


\section{CONCLUSION}

Promoting people participation in forest management requires concerted efforts on the part of government, NGOs, academic institutions and the people themselves. In the short term, the state should create incentives to allow local people to benefit from its programs.

Community forestry as seen in some other countries is not just forest management, but a means to wider change and empowerment at the local level. Community forest management provides basic needs, generates income and strengthens local capacities to manage natural resources and the environment. It contributes to the development of human resources by raising awareness and fostering right attitudes, knowledge and skills through participatory learning. Eventually it will help to balance decision-making process between the central government and local communities. The experiences about the involvement of the local communities into the process are that the public meetings are a good way to give information. Public awareness has to be created and the local people (user groups) have to be involved in all stages of community forestry development.

Therefore, to expand and increase the benefits of $\mathrm{CF}$ for rural livelihoods, education and extension services should be strengthened to render communities and extension agents more aware of the potential of more $\mathrm{CF}$ in the rural areas. Furthermore, the government should give due emphasis and continued support to the rural communities in promoting increased CF participation, as this program supports the improvement of rural livelihoods.

The communities should be also more aware of forest acts, rules, regulations and the purpose of protecting and managing the forest. They should be concerned about their ownership rights over $\mathrm{CF}$ in the event that the government decides to back their ownership, making changes in the forest acts, rules and regulations in the future.

A notable observation of the research was that local people play a crucial role in forest conservation. When they are organized in community-based organization, they play a critical role in successful negotiation and joint management between local people and the government. In fact, forest management is a socio-economic process in which different stakeholders claiming an interest in specific resources. Hence, At Present, forest conservation is impossible unless government resources and expertise are combined with the capabilities of other stakeholders, particularly local people. In order to enhance people capacities in forest conservation, they should be provided with essential training, credit, sustainable livelihood, incomegenerating and reliable employment, a defined and clear collaboration protocol with the government as well as legal and political supports. From the other part, the government agencies should be ensured that all the staff member and field agents are well-trained and informed about technical as well as socio-economic aspects of forest management.

The study revealed that forest conservation needs a public will to first expand people perception and knowledge about the values of forest and secondly involve them at different stages in forest management. The government has to take the process of decentralization and privatization of forest management into consideration through which local people undertake more responsibilities. Participation at the villagers requires relevant and effective incentives to encourage and motivate local people and institutes to share their resources with the government capabilities for better forest management. The information indicated that lack of long-term planning and high depending of the people to government's remittances and subsides are two problems limiting capacitybuilding of stakeholders for participatory forest management. Therefore, it is concluded that empowerment of rural people and community development will be useful and essential to improve people-government linkages for joint forest management. One of the basic needs for effective people participation is to create and develop sense of ownership towards forest resources among the inhabitants. Another advantage of people participation is due to the shortage of government facilities and personnel to cover whole forested area. According to the information obtained through PRA method the following solutions are recommended to improve participatory forest management:

- Improving sense of ownership towards forest resources among local people

- Diversifying income-generating sources of local people

- Capacity-building and empowerment of forests about participatory forest management

- Decentralizing forest management by providing appropriate incentives for local people

- Poverty reduction and enhancing sustainable livelihood at rural people 


\section{REFERENCES}

1. Abbasi, E., 2001. Investigating global experiences of promoting local participation in forest resource management and benefiting from successful experiences in Iran. Proceeding of National Conference on the Management of North Forests and Sustainable Development. Gostare Publication, Iran.

2. Amani, M., 2006. Village-living in Iran, strategies and policies. National Forest and Rangelands Research Institute.

3. Amani, M. and F.Ghasriani, 2006. Integrating forestry-animal husbandry into rural peripheral and indigenous forests. Monthly Mag. Dehati, 4.

4. Barbara, S., 2002. Participatory Rural Appraisal for Community Forest Management. http://www.communityforestryinternational.org/pu blications/field_methods_manual/pra_manual_tool s_and_techniques.pdf.

5. Borrini Feyerabend, G., M. Pimbert, M.T. Farvar, A. Kothari and Y. Renard, 2007. Sharing Power. Earthscsn, USA., ISBN: 1843694441.

6. Conroy, C., 2002. PRA Tools used for research into common pool resources. http://www.dfid.gov.uk/Pubs/files/BPG12.pdf.

7. Forest, Range and Watershed Management Organization, 2005. National report to the fifth session of the United Nations Forum on Forests. http://forestportal.efi.int/view.php?id=1632\&r=3.

8. FAO., 2002. FAO, forestry in Iran, online, viewed 18 February 2008.

9. FAO., 2002. The Forest Manager's guide to Participatory Forest Management: Module 1, Organizational change for participatory forest management. Forestry Policy and Institutions Branch, Forestry Department.
10. Shams-Allah, S.N. and M. Esperi, 2000. Openended expert meeting on special needs and requirements of developing countries with low forest cover and unique types of forests. http://www.lfccs.net/concept.htm.

11. Gombya, W.S. and Y.A. Banana, 1995. Community participation in forest management: The case of Buto-buvuma Forest Reserve, Mpigi District, Uganda. http://www.umich.edu/ ifri/Publications/X7760B1 1-R001-16.pdf.

12. Jamshidian, S., 2006. Traditional forestry in Havarekhol village of Kurdistan Province in Iran. Q. J. Mountain Environ., 2: .

13. Noss, S. and Y. Allen, 2007. Glossary of Conservation Terms. https://www.msu.edu/ jaroszjo/greenway/glossary/ glossary.htm.

14. Poffenberger, M., B. McGean, A. Khare and J. Campbell, 1992. Community Forest Economy and Use Patterns: Participatory Rural Appraisal (PRA) Methods in South Gujarat, India. http://www.mekonginfo.org/mrc_en/doclib.nsf/0/A AE541D03E7D01D6C725679300238982/\$FILE/F ULLTEXT.html\#contents.

15. Shabanali, F.H., A.H. Alibaigi and A. Sharifzadeh, 2004. Approaches and Techniques of Participation in Agricultural Extension and rural development. Iranian Rural Development Institute, Tehran, Iran.

16. UNESCO, 2008. UNESCO Natural Science, online, viewed20 January 2008.

17. Wani, M. and A. Kothari, 2007. Protected areas and human rights in India-the impact of the official conservation model on local communities. Policy Matt., 15: 100-114.

18. World Bank, Agriculture Technology and Services Division (AGRTN), 1994. Agriculture Technology Notes. No. 6. Washington, DC. 